\author{
Małgorzata FEDORCZAK-CISAK ${ }^{1}$ \\ Alicja KOWALSKA-KOCZWARA ${ }^{2}$
}

\title{
ANALIZA MOŻLIWOŚCI ZAPEWNIENIA KOMFORTU AKUSTYCZNEGO I WIBRACYJNEGO POMIESZCZEŃ PRZY UŻYCIU MATERIAŁÓW ENERGOOSZCZECDNYCH
}

\begin{abstract}
Komfort użytkowania pomieszczeń coraz częściej jest przedmiotem badań naukowych na całym niemalże świecie, a firmy produkujące materiały izolacyjne prześcigają się w ofercie materiałów mających zapewnić komfort w naszych domach. Dzieje się tak ponieważ wzrastają możliwości techniczne stosowania nowych technologii w materiałach budowlanych, ale wzrasta również świadomość samych użytkowników obiektów budowlanych. W niniejszym artykule podjęto próbę analizy możliwości zapewnienia dwóch rodzajów komfortu użytkowania pomieszczeń: komfortu akustycznego i wibracyjnego. Parametry komfortu akustycznego i wibracyjnego pomieszczeń łączy fizyka tych zjawisk, a w kontekście budownictwa wspólnym mianownikiem są przegrody poziome (stropy). Rozpatrywaną w artykule analizę możliwości zapewnienia komfortu akustycznego i wibracyjnego oparto o występujące na rynku polskim produkty izolacyjne. Dokonano przeglądu materiałów izolacyjnych pod kątem możliwości ich wykorzystania do celu zapewnienia komfortu akustycznego i wibracyjnego w pomieszczeniach użytkowych. Podjęto również próbę doboru optymalnego materiału izolacyjnego, który spełniałby obydwa rozważane aspekty komfortu użytkowania pomieszczeń. Temat ten stanowi część większej analizy jakiej podjęły się autorki, mianowicie możliwości zapewnienia komfortu użytkowania pomieszczeń jako całości z uwzględnieniem również komfortu cieplnego, wizualnego czy jakości powietrza wewnętrznego. Część z tych aspektów komfortu użytkowania pomieszczeń uregulowana jest prawnie w Dyrektywach Unijnych, w krajowych aktach prawnych bądź też w normatywach międzynarodowych lub krajowych. W niniejszym artykule zestawiono również główne akty prawne zawierające wymagania w odniesieniu do konieczności zapewnienia komfortu akustycznego i wibracyjnego pomieszczeń.
\end{abstract}

Słowa kluczowe: materiały izolacyjne, wibroizolacje, drgania, budynki niskoenergetyczne

\footnotetext{
${ }^{1}$ Autor do korespondencji: Małgorzata Fedorczak-Cisak, Politechnika Krakowska, ul. Warszawska 24, 31-155 Kraków, tel. 6960460 50, e-mail: mporanna@wp.pl

2 Alicja Kowalska-Koczwara, Politechnika Krakowska, ul. Warszawska 25, 31-155 Kraków, tel. (012) 628-21-21, e-mail: alicja.kowalska.koczwara@gmail.com
} 


\section{Wymagania akustyczne i wibracyjne w pomieszczeniach użytkowych}

Pierwsze zalecenia dotyczące zapewnienia komfortu akustycznego i wibracyjnego można znaleźć w [1]. Dyrektywa [1] stawia 6 podstawowych wymagań w stosunku do właściwości użytkowych budynków. Dotyczą one:

- nośności i stateczności,

- bezpieczeństwa pożarowego,

- higieny zdrowia i środowiska,

- bezpieczeństwa użytkowania, ochrony przed hałasem,

- oszczędności energii i izolacyjności termicznej.

Za dyrektywą [1], ustawa [2] wprowadza zestaw wymagań użytkowych, jakim powinny odpowiadać budynki - w tym ochronę przed hałasem, uzupełniając wymagania akustyczne w zakresie ochrony przed drganiami odbieranymi w sposób bierny przez człowieka znajdującego się w budynku; ochrona przed hałasem mieści się także w zakresie obowiązku ochrony interesów osób trzecich w procesie projektowania, wykonywania i eksploatacji obiektu budowlanego.

Z kolei w [3] zagadnieniu ochrony przed hałasem i drganiami poświęcony jest dział IX, w którym określono zakres i sposób ochrony budynku i jego otoczenia, ze wskazaniem na wymagania akustyczne ujęte w normach technicznych. Istotę wymagań $\mathrm{w}$ ochronie przeciwdźwiękowej i przeciwdrganiowej bardzo dobrze oddaje $\S 325$ (zamieszczony jako pierwszy w dziale IX), który brzmi: „Budynek i urządzenia z nim związane powinny być zaprojektowane i wykonane w taki sposób, aby poziom hałasu, na który będą narażeni użytkownicy lub ludzie znajdujący się $\mathrm{w}$ ich sąsiedztwie, nie przekraczał poziomu stanowiącego zagrożenie dla ich zdrowia, a także umożliwiał im pracę, odpoczynek i sen w zadowalających warunkach". Sformułowanie to jest bardzo bliskie definicji wymagania podstawowego $\mathrm{nr} 5$ „Ochrona przed hałasem” wg [4]. Aby nadać techniczny sens temu wymaganiu w Rozporządzeniu [3] wyszczególniono szereg zagadnień, które muszą być uwzględnione przy projektowaniu budynku:

- odpowiednia ze względów akustycznych lokalizacja budynków mieszkalnych, zamieszkania zbiorowego i użyteczności publicznej: zalecenie sytuowania w miejscach najmniej narażonych na występowanie hałasów i drgań,

- zmniejszenie zagrożenia budynku hałasem i drganiami - przez zachowanie odległości między źródłami hałasów i drgań a budynkami z pomieszczeniami wymagającymi ochrony przed zewnętrznym hałasem i drganiami, a także stosowanie odpowiednich zabezpieczeń wibroakustycznych w postaci odpowiedniego ukształtowania budynku, stosowania elementów amortyzujących drgania oraz osłaniających i ekranujących przed hałasem, a także racjonalnego rozmieszczenia pomieszczeń w budynku, przy czy stopień ochrony powinien odpowiadać Polskim Normom, określającym dopuszczalne poziomy ha- 
łasu w pomieszczeniach oraz określającym zasady oceny wpływu drgań na ludzi w budynkach,

- odpowiednie właściwości akustyczne przegród wewnętrznych i zewnętrznych w budynku,

- jakość akustyczna stosowanych w budynku urządzeń stanowiących techniczne wyposażenie budynku,

- zabezpieczenia przeciwdźwiękowe i przeciwdrganiowe w instalacjach ograniczające powstawanie hałasów i drgań oraz rozprzestrzeniania się ich w budynku i przenikania do otoczenia budynku.

Załącznik do rozporządzenia [3] „Wykaz Norm Polskich przywołanych w rozporządzeniu" podaje następujące normy odnoszące się do Działu IX „Ochrona przed hałasem i drganiami”:

- PN-87/B-02151.02, „Dopuszczalne wartości poziomu dźwięku w pomieszczeniach", określa dopuszczalne poziomy hałasu przenikającego do pomieszczeń podlegających ochronie akustycznej,

- PN-B-02151-3:1999, „Izolacyjność akustyczna przegród w budynkach i izolacyjność akustyczna elementów budowlanych. Wymagania", określa minimalne właściwości akustyczne przegród wewnętrznych i zewnętrznych w budynku,

- PN-88/B-02171, „Ocena wpływu drgań na ludzi w budynkach”, określa dopuszczalne poziomy drgań przenoszonych na konstrukcję budynku i odbieranych w sposób bierny przez człowieka przebywającego w budynku,

- PN-85/B-02170, „Ocena szkodliwości drgań przekazywanych przez podłoże na budynki" podaje metody oceny wpływu drgań na budynki wprowadzając metodykę szczegółowej oceny oraz oceny przybliżonej według skal SWD, którym podlegają budynki zwarte do 5 kondygnacji o konstrukcji murowej.

Zestaw zagadnień wymienionych w Rozporządzeniu [3], które powinny być uwzględnione przez projektanta budynku stanowi listę problemów dotyczących ochrony przeciwdźwiękowej i przeciwdrganiowej budynku wraz z ogólnym wskazaniem sposobów ich rozwiązania. Zgodnie z tym zestawieniem powinien być analizowany projekt każdego budynku i oceniane skutki akustyczne przyjętych rozwiązań.

\section{Wymagania izolacyjności akustycznej przegród wewnętrz- nych w budynkach}

Wymagania dla budynków w zakresie izolacyjności akustycznej przegród wewnętrznych podane są w normie [5]. Odniesione są one do izolacyjności akustycznej przy uwzględnieniu wszystkich dodatkowych, pośrednich dróg transmisji dźwięku między pomieszczeniami. Wytyczne, o których mowa poniżej są zgodne także z normami [6] i [7].

Izolacyjność akustyczna od dźwięków powietrznych (stosowana przy ocenie izolacyjności akustycznej ścian wewnętrznych i stropów oraz drzwi wejścio- 
wych do mieszkań) określana jest za pomocą tzw. wskaźnika oceny przybliżonej izolacyjności akustycznej właściwej $\mathrm{R}_{\mathrm{A1}}[\mathrm{dB}]$ lub $\mathrm{R}_{\mathrm{A}_{2}}[\mathrm{~dB}]$. Określenie „przybliżona" wskazuje, że odnosi się ona do właściwości akustycznych przegrody po jej zamontowaniu w budynku. Izolacyjność akustyczna przegród wewnętrznych w budynku nie jest równoznaczna z izolacyjnością akustyczną danego rozwiązania materiałowo-konstrukcyjnego przegrody określoną w warunkach laboratoryjnych. Izolacyjność akustyczna przegrody budowlanej jako wyrobu jest zawsze mniejsza od izolacyjności akustycznej, jaką osiągnie ta przegroda po jej zamontowaniu w budynku. Jest to wynikiem nie tylko jakości wykonawstwa, ale także skutkiem rozprzestrzeniania się dźwięku drogami materiałowymi po konstrukcji budynku, a w szczególności przegrodami bocznymi w stosunku do rozpatrywanej przegrody.

Wskaźnik oceny przybliżonej wyrażony jest głównie w postaci wskaźnika $\mathrm{R}_{\mathrm{Al}}{ }^{\prime}$, który uwzględnia $\mathrm{w}$ zasadach oceny widmo hałasu bytowego występującego w budynkach mieszkalnych. W przypadkach szczególnych występowania $\mathrm{w}$ pomieszczeniu hałasu niskoczęstotliwościowego stosuje się wskaźnik

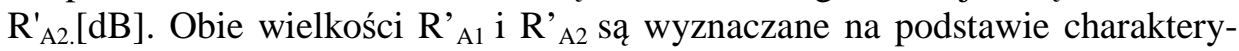
styki R' w funkcji częstotliwości oraz poniższymi wzorami:

$$
R_{A l}^{\prime}=R^{\prime} w+C
$$

gdzie: R'w - ważony wskaźnik przybliżonej izolacyjności akustycznej właściwej $[\mathrm{dB}]$,

C- widmowy wskaźnik adaptacyjny dostosowany do płaskiego widma w funkcji częstotliwości charakteryzującego hałas bytowy w budynkach mieszkalnych $[\mathrm{dB}]$.

$$
R_{A 2}^{\prime}=R^{\prime} w+C_{t r}
$$

gdzie R’w - ważony wskaźnik przybliżonej izolacyjności akustycznej właściwej $[\mathrm{dB}]$,

$\mathrm{C}_{\text {tr }}$ - widmowy wskaźnik adaptacyjny dostosowany do hałasu niskoczęstotliwościowego [dB], np. dyskoteki.

Wskazówki, który wskaźnik $\mathrm{R}_{\mathrm{A} 2}$ czy $\mathrm{R}_{\mathrm{A} 1}$ stosować w konkretnej sytuacji wynikającej z zakresu obowiązywania widmowych wskaźników adaptacyjnych $\mathrm{C}_{\mathrm{tr}} \mathrm{i}$ C zestawiono w tablicy 1.

Izolacyjność akustyczna od dźwięków uderzeniowych (stosowana przy ocenie stropów międzykondygnacyjnych przy uwzględnieniu wszystkich kierunków przenoszenia dźwięków w budynku) wyrażana jest za pomocą ważonego wskaźnika przybliżonego znormalizowanego poziomu uderzeniowego L'n,w. 
Tablica 1. Wskazówki do stosowania wskaźników $\mathrm{R}_{\mathrm{A} 2}$ i R' $\mathrm{R}_{\mathrm{A} 1}$ przy przyjmowaniu wymagań izolacyjności akustycznej przegród zewnętrznych, na podstawie [6]

Table 1. Guidelines for the use of indicators $\mathrm{R}_{\mathrm{A} 2}^{\prime}$ and $\mathrm{R}_{\mathrm{A} 1}^{\prime}$ in the adoption requirements of sound insulation of external walls, based on [6]

\begin{tabular}{|l|l|}
\hline \multirow{2}{*}{ Wskaźnik } & \multicolumn{1}{|c|}{ Rodzaj źródła hałasu zewnętrznego } \\
\hline $\mathrm{C}[\mathrm{dB}]$ & Komunikacja drogowa w mieście \\
\cline { 2 - 2 } & $\begin{array}{l}\text { Komunikacja lotnicza - przeloty samolotów w dużej odległości od } \\
\text { lotniska }\end{array}$ \\
\cline { 2 - 2 } & $\begin{array}{l}\text { Komunikacja kolejowa - przejazd pociągów z prędkością mniejszą niż } \\
80 \mathrm{~km} / \mathrm{h}\end{array}$ \\
\hline $\mathrm{C}_{\mathrm{tr}}[\mathrm{dB}]$ & Komunikacja drogowa na utostradach i drogach szybkiego ruchu \\
\cline { 2 - 2 } & $\begin{array}{l}\text { Komunikacja lotnicza - przeloty samolotów w małej odległości od } \\
\text { lotniska }\end{array}$ \\
\cline { 2 - 2 } & $\begin{array}{l}\text { Komunikacja kolejowa - przejazd pociągów z prędkością większą niż } \\
80 \mathrm{~km} / \mathrm{h}\end{array}$ \\
\hline
\end{tabular}

Aby przy projektowaniu budynku prawidłowo przyjąć wymaganą izolacyjność akustyczną przegród zewnętrznych powinny być uprzednio określone warunki akustyczne w miejscu lokalizacji budynku. Należy przy tym uwzględnić samoekranowanie poszczególnych elewacji przez bryłę budynku w wyniku czego mogą zaistnieć przypadki, że będą zróżnicowane wymagania akustyczne przegród zewnętrznych przy poszczególnych elewacjach budynku.

W niniejszym artykule podjęto próbę znalezienia części wspólnej komfortu akustycznego i wibracyjnego dlatego też rozważania dotyczące akustyki pomieszczeń odnoszą się wyłącznie do przegród poziomych (stropów). Pełna ocena akustyczna powinna oczywiście też uwzględniać emisję hałasu poprzez przegrody pionowe.

Wymagane wartości wskaźników izolacyjności akustycznej przegród wewnętrznych w budynkach zestawiono w tablicy 2 .

Wartości w tabeli podane w zakresach „od do” dotyczą możliwości wystąpienia różnych poziomów hałasu w pomieszczeniu nadawczym w zależności od jego przeznaczenia. 
Tablica 2. Wymagane wartości wskaźników izolacyjności akustycznej przegród wewnętrznych w wybranych budynkach mieszkalnych, na podstawie [5]

Table 2. Required values of sound insulation of internal partitions in chosen buildings, based on [5]

\begin{tabular}{|c|c|c|c|c|}
\hline \multirow[b]{2}{*}{ Lp. } & \multirow{2}{*}{$\begin{array}{l}\text { Przeznaczenie } \\
\text { budynku }\end{array}$} & \multirow{2}{*}{$\begin{array}{c}\text { Rodzaj } \\
\text { przegrody wewnętrznej }\end{array}$} & \multicolumn{2}{|c|}{ Wymagania w dB } \\
\hline & & & $\begin{array}{l}\min . R^{\prime}{ }_{A 1} \\
\text { lub R' }{ }_{A 2}^{\prime}\end{array}$ & $\begin{array}{l}\max . \\
\text { L'n,w }\end{array}$ \\
\hline 1 & \multirow{6}{*}{$\begin{array}{l}\text { Budynki mieszkal- } \\
\text { ne wielorodzinne }\end{array}$} & Ściana międzymieszkaniowa & 50 & \\
\hline 2 & & Strop międzymieszkaniowy & 51 & 58 \\
\hline 3 & & $\begin{array}{l}\text { Ściana między mieszkaniem a } \\
\text { pomieszczeniem technicznym }\end{array}$ & $55-57$ & - \\
\hline 4 & & $\begin{array}{l}\text { Strop między mieszkaniem a } \\
\text { pomieszczeniem technicznym }\end{array}$ & $55-57$ & $48-58$ \\
\hline 5 & & $\begin{array}{l}\text { Ściany działowe w obrębie } \\
\text { mieszkania }\end{array}$ & $30-35$ & - \\
\hline 6 & & Drzwi wejściowe do mieszkań & 25 & - \\
\hline 7 & \multirow{2}{*}{$\begin{array}{l}\text { Budynki jednoro- } \\
\text { dzinne w zabudo- } \\
\text { wie szeregowej }\end{array}$} & Ściany między budynkami & $52-55$ & - \\
\hline 8 & & $\begin{array}{l}\text { Strop - przenoszenie dźwię- } \\
\text { ków uderzeniowych do obce- } \\
\text { go budynku }\end{array}$ & - & 53 \\
\hline 9 & \multirow{3}{*}{$\begin{array}{l}\text { Budynki jednoro- } \\
\text { dzinne wolnostoją- } \\
\text { ce }\end{array}$} & $\begin{array}{l}\text { Strop między pomieszczenia- } \\
\text { mi mieszkalnymi }\end{array}$ & 45 & 63 \\
\hline 10 & & $\begin{array}{l}\text { Ściany bez drzwi między } \\
\text { pokojami }\end{array}$ & 30 & - \\
\hline 11 & & $\begin{array}{l}\text { Ściany między pokojami a } \\
\text { pomieszczeniami sanitarnymi }\end{array}$ & 35 & - \\
\hline
\end{tabular}

\section{Wymagania dotyczące komfortu wibracyjnego w budynkach}

Podstawowym poziomem odniesienia w ocenie wpływu drgań na ludzi jest tzw. próg odczuwalności drgań. Wyniki badań w tym zakresie przyjęto za podstawę sformułowania kryteriów oceny wpływu drgań na ludzi. Jeśli drgania w miejscu ich odbioru przez człowieka są scharakteryzowane wartościami poniżej odpowiadających progowi odczuwalności drgań, to można je uznać za nieodczuwalne przez człowieka.

W badaniach testowych i weryfikujących uzyskuje się również informacje o parametrach charakteryzujących drgania, które jeszcze zapewniają ludziom warunki odpowiedniego komfortu wibracyjnego. Drgania o parametrach większych od opisanych wyżej uznaje się za naruszające warunki niezbędnego komfortu do wykonywania przez człowieka zadań określonych przeznaczeniem pomieszczenia (np. biurowe, mieszkalne, szpitalne itp.). 
Na tej podstawie można stwierdzić, że obecnie stosowane są trzy metody i odpowiadające im kryteria oceny, w których stosuje się następujące parametry:

a) wartość przyspieszenia (prędkości) drgań skorygowana w całym paśmie częstotliwości,

b) widmo (strukturę częstotliwościową) wartości skutecznej (RMS) przyspieszenia (prędkości) drgań w pasmach 1/3 oktawowych,

c) dawkę wibracji.

Najczęściej wykorzystywana jest metoda RMS - widmo wartości skutecznej w pasmach 1/3 oktawowych (por. [8]). Dzięki tej metodzie uzyskuje się informacje nie tylko o ewentualnym naruszeniu komfortu wibracyjnego, ale także o paśmie częstotliwości, w którym to naruszenie nastąpiło. W ocenie wpływu drgań na ludzi stosuje się zgodnie z normą [8] dwa poziomy odniesienia: próg odczuwalności drgań oraz próg komfortu drgań. Wartości mieszczące się poniżej progu odczuwalności drgań uznaje się za nieodczuwalne przez człowieka. Drgania mieszczące się pomiędzy progiem odczuwalności drgań a progiem komfortu uznaje się za drgania, które mogą być odczuwalne przez człowieka, przez co mogą u części osób powodować dyskomfort. Natomiast drgania sklasyfikowane powyżej poziomu komfortu drgań uznaje się za drgania, które mogą uniemożliwiać wykonywanie przez człowieka zadań określonych przeznaczeniem pomieszczenia i tego poziomu nie należy przekraczać. Metoda RMS ma jedną wadę, tylko w sposób pośredni uwzględnia czas trwania drgań a właściwie ich krotność. Charakter drgań, pora dnia, w której drgania występują czy przeznaczenie pomieszczenia ujęte są we współczynniku „n”. Współczynnik ten przemnożony przez rzędne linii wyznaczającej próg odczuwalności drgań wyznacza położenie progu komfortu wibracyjnego.

Nie tylko jednak czynniki opisane współczynnikiem „n” mogą wpływać na odbiór drgań przez ludzi. Można zauważyć podczas pomiarów in-situ, że także konstrukcja stropu podobnie jak to jest w akustyce może wpływać na tę odczuwalność. W przypadku stropów drewnianych bowiem próg odczuwalności drgań (czy nawet próg komfortu) jest częściej przekraczany niż w przypadku stropów o konstrukcji żelbetowej (por.rys.1).

Zestawione na rys. 1 wykresy RMS zostały sporządzone w oparciu o dane pomiarowe uzyskane na jednym budynku na dwóch różnych rodzajach stropów: a) żelbetowym i b) drewnianym. Dla stropu żelbetowego nastąpiło co prawda przekroczenie komfortu, ale tylko w porze nocnej (linia 1,4 az), podczas gdy dla stropu drewnianego wystąpiło przekroczenie warunków komfortu także w porze dziennej (linia $4 \mathrm{az}$ ).

Kryteria oceny wpływu drgań na ludzi, jeśli w ocenie stosowana jest dawka wibracji (normy $[9,10,11]$ ) są zbliżone co do sposobu ujęcia problemu do wskaźników izolacyjności akustycznej. W ocenie przy pomocy dawki wibracji podobnie jak przy ocenie izolacyjności akustycznej mamy do czynienia z wartościami, których nie powinno się przekraczać. Dawka wibracji wyrażana $\mathrm{w} \mathrm{m} / \mathrm{s}^{1,75}$ uwzględnia wpływ czasu trwania drgań (tzw. czas ekspozycji na drga- 
nia) co również jest podobne do ujęcia wpływu hałasu. W tablicy 3 (za [11]) zestawiono te właśnie wartości stanowiące kryterium oceny wpływu drgań na ludzi w budynkach, przebywających w pomieszczeniach mieszkalnych.

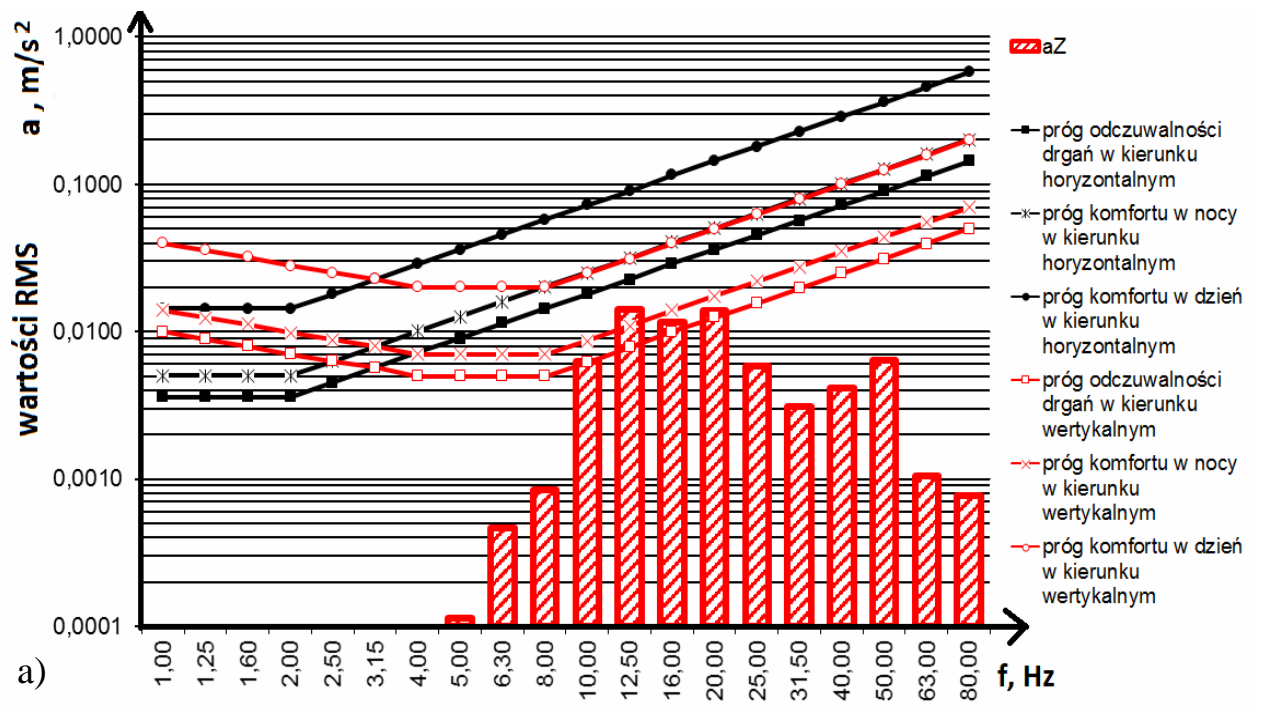

częstotliwość

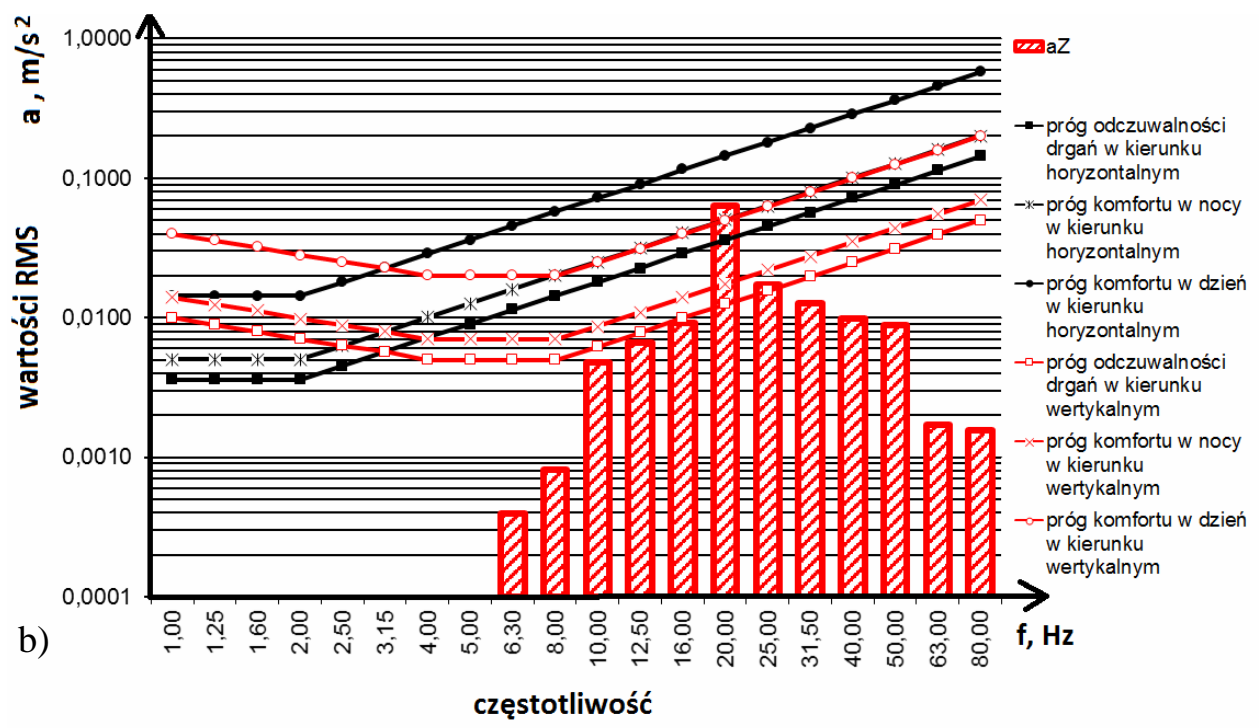

Rys. 1. Analiza RMS dla stropu: a) żelbetowego, b) drewnianego

Fig. 1. RMS analysis for floor made of: a) reinforced concrete, b) wood 
Tablica 3. Kryteria oceny wpływu drgań na ludzi w zależności od wartości VDV, za [11]

Table 3. Evaluation criteria of the vibration influence on people depending on the VDV value, by [11]

\begin{tabular}{|l|c|c|c|}
\hline \multicolumn{1}{|c|}{$\begin{array}{c}\text { Przeznaczenie } \\
\text { budynku }\end{array}$} & $\begin{array}{c}\text { Małe prawdopo- } \\
\text { dobieństwo skarg } \\
\text { VDV [m/s1,75] }\end{array}$ & $\begin{array}{c}\text { Skargi możliwe } \\
\text { VDV [m/s1,75] }\end{array}$ & $\begin{array}{c}\text { Skargi prawdopo- } \\
\text { dobne } \\
\text { VDV [m/s1,75] }\end{array}$ \\
\hline $\begin{array}{l}\text { Budynki mieszkalne - } \\
\text { dzień }\end{array}$ & $0,2-0,4$ & $0,4-0,8$ & $0,8-1,6$ \\
\hline $\begin{array}{l}\text { Budynki mieszkalne - } \\
\text { noc }\end{array}$ & 0,13 & 0,26 & 0,51 \\
\hline
\end{tabular}

W normie [10] wprowadzono również trzy poziomy rozgraniczające, które oznaczono: $\mathrm{A}_{\mathrm{u}}$ - próg odczuwalności, $\mathrm{A}_{\mathrm{r}}$ - średnie warunki komfortu oraz $\mathrm{A}_{\mathrm{o}}$ górna granica zapewnienia niezbędnego komfortu wibracyjnego.

\section{Dobór materiału izolacyjnego mogącego spełniać warunki komfortu akustycznego i wibracyjnego}

Komforty akustyczny i wibracyjny są pożądane zarówno w pomieszczeniach mieszkalnych, w których jego użytkownicy chcą odpocząć jak i w miejscu pracy. Osoby narażone na ciągłe oddziaływanie zarówno hałasu jak i drgań (te czynniki często się ze sobą łączą np. ruch uliczny) wystawiają się na ryzyko poważnych schorzeń. To mogą być schorzenia słuchu, ale także układu ruchu czy równowagi. Oprócz aspektów fizycznych problem długiej ekspozycji na odziaływanie hałasu czy drgań może prowadzić do licznych zaburzeń psychicznych od lekkich typu przemęczenie poprzez zaburzenia koncentracji do ciężkich stanów lękowych [13]. W miejscu pracy takie oddziaływania skutkują obniżeniem wydajności pracowników. Dlatego przy niemożności usunięcia źródła hałasu czy drgań konieczne jest zastosowanie odpowiednio dobranej izolacji akustycznej i/lub wibroizolacji. Ponieważ jak pisano wyżej te niekorzystne zjawiska często występują razem można pokusić się o dobór izolacji, która spełniałaby warunki zarówno komfortu akustycznego jak i wibracyjnego. I tu pojawia się problem, firmy produkujące materiały izolacyjne oddzielają akustykę od drgań i powodują co najmniej dwa typy rozwiązań dla każdego z tych zjawisk po jednym (np.[12]). Przykład materiałów izolacyjnych do stosowania w przegrodach poziomych (stropach) podano na rys. 2.

$\mathrm{Z}$ zestawienia pokazanego na rys. 2 widać, że producenci materiałów izolacyjnych ograniczają komfort wibracyjny tylko do obiektów przemysłowych i pojazdów mechanicznych zaniedbując obiekty mieszkalne. W związku z powyższym autorki niniejszej pracy podjęły trud znalezienia materiału, który przy swoich właściwościach akustycznych będzie także spełniał warunki komfortu wibracyjnego. Podjęty temat będzie zawierał analizę występujących na rynku produktów, analizę numeryczną oraz badania in-situ przeprowadzone na obiekcie w skali naturalnej. Wyniki prac zarówno symulacji jak i prac doświadczalnych zostaną zaprezentowane w kolejnych publikacjach. 


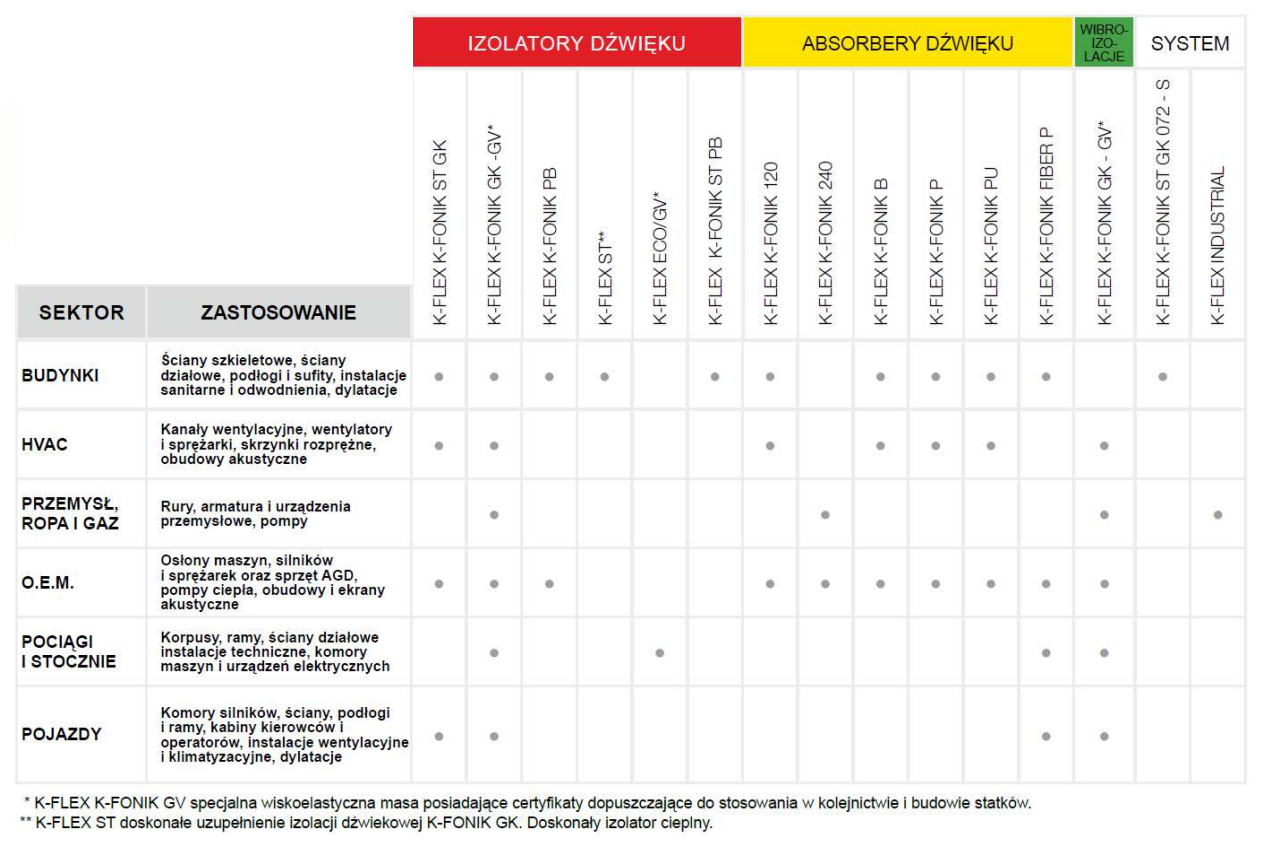

Rys. 2. Możliwości zastosowania materiałów firmy K-flex, za [12]

Fig. 2. Possibilities of application materials K-flex, by [12]

\section{Wnioski i kierunki prac}

Projektowanie budynków energooszczędnych czy niemal zero energetycznych, jest dla projektantów wyzwaniem nie tylko pod kątem zapewnienia odpowiedniej ochrony cieplnej, ale również komfortu użytkowania obiektów na wysokim poziomie. Oprócz niskiego zużycia energii, budynki energooszczędne muszą być również przyjazne dla użytkowników. Na odczucia komfortu wpływają odczucia użytkowników związane między innymi z odbieraniem dźwięków oraz odczuwalnością drgań. Są to ważne aspekty wpływające także na zdrowie człowieka. Wybór materiałów konstrukcyjno-budowlanych na etapie projektowania budynku może zminimalizować wszelkie zagrożenia związane z przekroczeniem komfortu użytkowania budynku. Autorki zasygnalizowały potrzebę wprowadzenia przez producentów materiałów budowalnych na rynek, produktów spełniających wymagania komfortu równolegle w różnych aspektach, np. zapewniających ochronę izolacyjności akustycznej, cieplnej oraz tłumiącej drgania zewnętrzne. Nieodzownym elementem „,dobrych praktyk” projektowania budynków energooszczędnych jest zwiększenie świadomości projektantów przy wyborze odpowiednich materiałów. W kolejnych pracach zasygnalizowanego w artykule tematu, Autorki zamierzają przeprowadzić szereg doświadczeń mających na celu stworzenie bazy materiałów budowlanych 
„przyjaznych” człowiekowi pod względem zapewnienia wieloaspektowego komfortu użytkowania budynku. Prace badawcze będą wykonywane w ramach Małopolskiego Centrum Budownictwa Energooszczędnego, które jest nowo powstałą jednostką Politechniki Krakowskiej i stanowi platformę współpracy naukowców i przedstawicieli gospodarki. Wyniki prac będą upowszechniane i będą stanowiły zbiór informacji na temat parametrów materiałów budowlanych zapewniających warunki komfortu w budynkach energooszczędnych.

\section{Literatura}

[1] Dyrektywa UE nr 89/106/EEC w sprawie zbliżenia przepisów prawnych i administracyjnych państw członkowskich dotyczących wyrobów budowlanych.

[2] Dz.U. 1994 Nr 89 poz. 414 Ustawa z dnia 7 lipca 1994. Prawo Budowlane.

[3] Rozporządzenie Ministra Infrastruktury z 12.04.2002 r. w sprawie warunków technicznych, jakim powinny odpowiadać budynki i ich usytuowanie.

[4] Dyrektywa 9/1006 EEC.

[5] PN-B-02151-3:1999 Akustyka budowlana- Ochrona przed hałasem z budynkach Izolacyjność akustyczna przegród $\mathrm{w}$ budynkach oraz izolacyjność akustyczna elementów budowlanych - Wymagania.

[6] PN-EN ISO 717-1:1999 Akustyka - Ocena izolacyjności akustycznej w budynkach i izolacyjności akustycznej elementów budowlanych - Izolacyjność od dźwięków powietrznych.

[7] PN-EN ISO 717-2:1999 Akustyka - Ocena izolacyjności akustycznej w budynkach i izolacyjności akustycznej elementów budowlanych - Izolacyjność od dźwięków uderzeniowych.

[8] PN-B-02170, 1988, Ocena wpływu drgań na ludzi w budynkach, norma polska

[9] BS 6472-1:2008, Guide to evaluation of human exposure to vibration in buildings, Part 1: Vibration sources other than blasting, 2008, British Standard.

[10] DIN 4150-2, Structural vibration, Part 2: Human exposure vibration in buildings, 1999, German Standard.

[11] ISO 10137 Bases for design of structures - Serviceability of buildings and walkways against vibration, 2007, International Organization for Standardization.

[12] http://www.kflex.com/index.php?lang=en. [dostęp: 31.05.2014].

[13] Uhryński A.: Badania wpływu drgań ogólnych niskiej częstotliwości na wybrane parametry funkcjonalne organizmu człowieka. Rozpraw doktorska, Kraków 2010.

\section{ANALYSIS OF POSSIBILITY TO PROVIDE ACOUSTIC AND VIBRATIONAL ROOMS COMFORT USING ENERGY SAVING MATERIALS}

\section{S u m m a r y}

Rooms comfort is increasingly the subject of research on almost entire scientific world, and companies producing insulation materials compete in the offer of materials that may provide 
comfort in our homes. This happens because technical possibilities of the use of new technologies in materials construction are increasing, but also increases awareness of building users. This article attempts to analyze the ability to provide two types of rooms comfort: acoustic and vibrational comfort. The parameters of acoustic and vibrational comfort of rooms combined the physics of this phenomena and in the context of building a common denominator are horizontal partitions (floors). The considered, in the article, analysis of possibilities to provide acoustic and vibrational comfort is based on present on the Polish market insulation products. A review of insulation materials in terms of their possible use to ensure acoustic and vibrational comfort in the utility rooms is being made. Attempt of the selection of the optimal insulation material which fulfills both consider aspects of the comfort rooms was also made. This subject is a part of a larger analysis which authors took into consideration, namely the ability to provide rooms comfort as a whole, and also taking into account the thermal, visual comfort or indoor air quality. Some of this aspects of the rooms comfort are regulated by law for EU Directives, in national legislation or international and national standards. This article summarizes the main regulations containing requirements for the need to ensure sound and vibrational rooms comfort.

Keywords: insulation materials, vibrational insulation, acoustic comfort, low energy buildings

Przestano do redakcji: 14.11.2014r.

Przyjęto do druku: 22.06.2015 r.

DOI:10.7862/rb.2015.35 